\title{
PENGARUH KECEPATAN PENGADUKAN DAN KEHALUSAN GAMBIR SERTA VARIASI KOMPOSISI TERHADAP BEBERAPA SIFAT FISIKA DALAM PEMBUATAN TINTA CETAK
}

\section{The Effect of Stirring Speed and Particle Size of Gambier and Variation of Composition on Some Physical Properties in Making of Printing Ink}

\author{
Hendri Muchtar*, Inda Three Anova, dan Gustri Yeni \\ Balai Riset dan Standardisasi Industri Padang \\ JI. Raya LIK No. 23 Ulu Gadut, Padang 25164 \\ *e-mail: hendrimuchtar@yahoo.co.id
}

Diterima: 2 September 2015, revisi akhir: 9 Desember 2015 dan disetujui untuk diterbitkan: 13 Desember 2015

\begin{abstract}
ABSTRAK
Tinta merupakan unsur yang sangat penting menentukan kualitas hasil cetakan. Salah satu bahan alam potensial yang dapat dijadikan sebagai bahan baku pembuatan tinta cetak adalah gambir. Penelitian ini bertujuan untuk mengamati pengaruh kecepatan pengadukan dan kehalusan bahan baku gambir terhadap beberapa sifat fisika dalam pembuatan tinta cetak. Pembuatan tinta dilakukan 2 tahap yaitu pembuatan pigmen dan formula tinta. Pigmen tinta dibuat dengan cara membersihkan gambir melalui pelarutan dengan air panas, penyaringan, dan pengendapan fitrat. Selanjutnya endapan gambir dihaluskan dengan variasi ukuran butiran sebesar 40, 60, 80 mesh. Penambahan senyawa $\mathrm{FeCl}_{3}$ jenuh dalam etanol pada ekstrak gambir dalam $25 \mathrm{ml}$ etanol secara perlahan dengan kecepatan pengadukan bahan sebesar 250, 500, $750 \mathrm{rpm}$ selama 4 jam. Pigmen diuji warna, viskositas, dan ukuran partikel dengan menggunakan metoda PSA (particle size analyzer). Pembuatan formula tinta dengan bahan aditif propilen glikol sebesar 7,$5 ; 10 ; 12,5 \mathrm{ml}$ dan polietilen glikol 0,$1 ; 0,3 ; 0,5 \mathrm{ml}$ untuk setiap 30 $\mathrm{ml}$ ektrak gambir dalam etanol. Pigmen terbaik diperoleh pada pemakaian bubuk gambir 60 mesh, kecepatan pengadukan $250 \mathrm{rpm}$, ukuran partikel pigmen yang terkecil adalah 47,54 nm. Formula tinta yang terbaik adalah tinta dengan menggunakan propilen glikol $12,5 \mathrm{ml}$ dan polielen glikol $0,5 \mathrm{ml}$. Karakteristik tinta bewarna hitam dengan berat jenis pada suhu $28-30^{\circ} \mathrm{C}$ sebesar 0.9633 , viskositas $0,9 \mathrm{cP}$ dan tegangan permukaan $0,2539 \mathrm{~N} / \mathrm{m}$.
\end{abstract}

\section{Kata Kunci: Ekstrak gambir, ukuran partikel, tinta cetak}

\begin{abstract}
Ink is a very important element that determines the quality of a printout. One of the potential natural materials that can be used as a raw material for making printing ink is gambier.The objective of this study was to observe the effect of stirring speed and particle size on some physical properties in the printing ink. The ink manufacturing was done in 2 phases, namely the manufacture of color pigment and ink formulation. Pigment ink was made by cleaning the gambier through dilution with hot water, filtration, and precipitation of fitrat. Furthermore the gambier was mashed with particle size variation 40,60, 80 mesh. The adding saturated $\mathrm{FeCl}_{3}$ compounds in ethanol into the extract gambier slowly with stirring speed 250, 500, 750 rpm for 4 hours. The color of the pigment, viscosity, and the particle size was tested by using the PSA method (particle size analyzer). Manufacture of ink formula with additives propylene glycol 7.5; 10; $12.5 \mathrm{~mL}$ and polyethylene glycol 0.1; 0.3; and $0.5 \mathrm{~mL}$ for every $30 \mathrm{ml}$ of extract gambier in ethanol. Best pigment was obtained from the use of gambier 60 mesh powder, stirring speed 250 $\mathrm{rpm}$, the smallest pigment particle was $47.54 \mathrm{~nm}$. The best ink formula was using propylene glycol and polyethylene glycol $12.5 \mathrm{~mL}$ and $0.5 \mathrm{~mL}$. The characteristics of ink were black colored ink with a density 0.9633 at a temperature of $28-30^{\circ} \mathrm{C}$, viscosity $0.9 \mathrm{cP}$, and surface tension $0.2539 \mathrm{Nm}^{-1}$.
\end{abstract}

Keywords: Gambier extract, particle size, printing Ink 


\section{PENDAHULUAN}

Tinta adalah bahan berwarna yang mengandung pigmen warna, digunakan diantaranya untuk mewarnai, menulis, mencetak dan menggambar. Tinta merupakan sebuah media yang sangat kompleks, berisikan pelarut, pigmen, celupan resin, dan pelumas, sollubilizer (senyawa yang membentuk ion-ion polimer polar dengan resin tahan air) dan surfaktan. Surfaktan adalah surface active agent (agen aktif permukaan) yang berguna untuk menurunkan tegangan permukaan atau tekanan antar permukaan antara dua cairan, materi-materi partikuler dan materialmaterial lainnya.

Komponen tinta berfungsi sebagai pembawa tinta, pewarna dan bahan-bahan aditif lainnya yang digunakan untuk mengatur aliran, ketebalan dan rupa tinta ketika kering. Pigmen atau zat pewarna mempunyai fungsi untuk memberikan warna dan membentuk bodi pada tinta serta memberikan lapisan warna pada permukaan hasil cetakan.

Zat pengikat atau varnish atau vehicle berupa media yang berfungsi untuk mengikat bahan pewarna. Bahan penolong digunakan untuk mendapatkan sifat-sifat tertentu pada tinta baik sifat kimia maupun sifat fisika seperti bahan pengisi, bahan pengering dan lainnya (Antono dan Sebastianus, 2013).

Pigmen merupakan bahan pewarna yang tidak dapat larut, butirnya lebih besar, lebih tahan terhadap cahaya, panas dan bahan kimia. Pigmen umumnya digunakan dalam tinta offset seperti pigmen anorganik lengas gas dan jelaga. Pigmen yang berasal dari zat warna alam merupakan zat warna yang secara alami ada di dalam jaringan tanaman dan hewan (Siva, 2007; Antono dan Sebastianus, 2013).

Formula tinta permanen dari bahan pewarna sintetis telah dibuat dari senyawa tripenil quanidin (Van lint et al., 1995), Swider et al., (2003) melakukan penelitian karakteristik tinta cina berbahan baku campuran jelaga dan lem binatang. Karakterisasi tinta dapat dilakukan dengan dengan metoda photon correlation spectroscopy (PCS) dan scanning electron microscopy (SEM).

Pemanfaatan pigmen warna dari bahan alam dilakukan oleh Ram Kumar et al., (2012). Formulasi dan standardisasi tinta permanen dibuat dari tanaman Beet vulgaris dan Curcuma longa. Peneltian pembuatan tinta dengan bahan baku pigmen warna alami yang ramah lingkungan juga dilakukan oleh Wiguna et al., (2014).

Pigmen warna dibuat serbuk karbon hasil pembakaran sampah daun yang digunakan sebagai pigmen pembawa warna hitam untuk tinta printer. Tinta Whiteboard dapat dibuat dengan memanfatkan arang jerami sebagai bahan dasar pembuatan tinta yang ramah lingkungan untuk menghindari volatile organic compound (VOC) (Suhartini et al., 2012).

Pemanfaatan bahan pewarna alami lainnya seperti tanaman Melastoma malabathricum L (harendong), Bixa orellana L (galinggeum), Lawsonia Inermis (pacar paku) dan Indigofera areccta (tarum) dapat dibuat sebagai bahan baku pembuatan tinta pemilu (Yelin, 2010). Berdasarkan hal tersebut penggunaan pigmen pada tinta sintetis dapat diganti dengan memakai zat warna alami dari bahan baku gambir (Uncaria gambir Roxb.).

Menurut SNI gambir No. 01-3391-2000, gambir adalah ekstrak yang diperoleh dari pengolahan daun dan tangkai tanaman gambir yang diendapkan, selanjutnya dicetak dalam berbagai bentuk dan dikeringkan.

Penggunaan pigmen tinta berbahan dasar gambir selain karena alasan kesehatan, tetapi juga ramah lingkungan. Penggunaan tinta dengan pigmen dari bahan baku alam memiliki beberapa keuntungan, yaitu mengurangi penggunaan pigmen tinta sintetis sebagai upaya penghematan produk impor serta turut memacu perkembangan temuan dan Iptek industri nasional. Industri pigmen tinta berbahan dasar bahan alam di Indonesia masih dalam tahap awal perkembangan. Eksplorasi tumbuhan yang dapat dimanfaatkan serta uji coba pembuatan tinta untuk pengembangan teknik produksi yang lebih efektif dan efisien perlu terus diupayakan. 
Komponen utama gambir adalah senyawa tanin sebagai asam katechu tannat (20-55\%) dan katechin (7-33\%). Kedua senyawa ini merupakan senyawa komplek yang digolongkan ke dalam golongan fenol alam dengan struktur flavonoid. Senyawa tanin memberikan rasa sepat dan menimbulkan warna kuning kecoklatan sampai hitam. Industri pewarna seperti tinta membutuhkan kandungan tanin yang tinggi.

Gambir dalam suasana basa dapat memberikan warna merah darah. Jika ditambahkan $\mathrm{FeCl}_{3}$ alkoholik dan $\mathrm{NaOH}$ jenuh akan memberikan warna biru sampai hitam (Hagerman, 2002; Muchtar dan Silfia, 2007).

Untuk mengatasi permasalahan tersebut maka perlu dilakukan penelitian pembuatan pigmen tinta dari ekstrak gambir melalui proses pembentukan senyawa kompleks besi tanin. Kecepatan pembentukan dan ukuran partikel pigmen yang dihasilkan sangat dipengaruhi antara lain oleh lama waktu pembentukan pigmen gambir. Makin halus partikel pigmen yang dihasilkan, makin baik digunakan untuk tinta cetak apalagi jika ukuran partikel sampai ukuran nanometer.

Partikel dengan ukuran nano merupakan material yang banyak diaplikasikan di berbagai macam industri di Indonesia maupun di dunia karena material dengan ukuran nano memiliki sifat kimia dan sifat fisika yang lebih unggul dibandingkan material berukuran besar atau dalam bentuk bulk (Lidiyah, 2011; Galuh dan Rahmi, 2014).

Penelitian ini bertujuan untuk mengamati pengaruh kecepatan pengadukan dan kehalusan bahan terhadap beberapa sifat fisika dalam pembuatan tinta cetak, terutama kehalusan pigmen tinta dari ekstrak gambir yang secara teknis dapat memenuhi persyaratan kualitas tinta.

\section{METODOLOGI PENELITIAN}

Bahan yang digunakan dalam penelitian ini adalah gambir yang berasal dari daerah Siguntur Kecamatan VII Koto Tarusan Kabupaten Pesisir Selatan. Bahan kimia proses adalah $\mathrm{FeCl}_{3}$ teknis, $\mathrm{NaOH}$ teknis, etanol teknis, air suling, dan bahan kimia untuk pengujian.
Peralatan yang digunakan meliputi alat ekstraksi skala laboratorium, saringan, pengaduk, corong pemisah, Whatman 42 , alat bantu seperti penggiling, stirer, timbangan, alat-alat gelas, viscometer, PSA dan peralatan pengujian lainnya. Pembuatan tinta dilakukan 2 tahap yaitu pembuatan pigmen dan formula tinta dengan proses seperti berikut ini.

\section{Pembuatan Pigmen.}

Pembuatan pigmen tahap awal dilakukan melalui proses pencucian gambir. Proses pencucian gambir dilakukan untuk membuang kotoran yang ada dalam gambir. Gambir asalan dihancurkan dan dilarutkan dengan air panas $\left(80-90^{\circ} \mathrm{C}\right)$, saring kotoran menggunakan kain saring dan diendapkan semalam (20-24 jam). Endapan gambir dipisahkan dan dipres untuk mengeluarkan air yang tersisa dengan menggunakan alat pres. Gambir yang telah kering dihaluskan kembali dan diayak (A) dengan ukuran ayakan 80 mesh (A1), 60 mesh (A2), dan 40 mesh (A3).

Gambir hasil ayakan ditimbang masingmasing 10 gram, dilarutkan dengan etanol teknis $(25 \mathrm{ml})$, diaduk menggunakan pengaduk dengan kecepatan $500 \mathrm{rpm}$ selama 3 jam. Larutan kemudian dimaserasi selama 1 malam (20-24 jam), saring dengan kertas saring (Whatman 42). Ekstrak yang diperoleh $( \pm 80 \%)$ selanjutnya digunakan untuk pembuatan pigmen sesuai perlakuan.

Pembuatan pigmen tinta dilakukan dengan menambahkan $\mathrm{FeCl}_{3}$ teknis alkoholik $(20 \mathrm{ml})$ ke dalam $25 \mathrm{ml}$ ekstrak gambir dalam etanol sesuai dengan variasi kehalusan. Penambahan senyawa $\mathrm{FeCl}_{3}$ teknis dilakukan dengan 2 cara, yaitu pada suasana basa dengan menambahkan $\mathrm{NaOH}$ jenuh $(10 \mathrm{ml})$ dan tanpa penambahan $\mathrm{NaOH}$. Penambahan $\mathrm{FeCl}_{3}$ teknis dilakukan secara perlahan atau tetes demi tetes (kecepatan tetes 0,2 $\mathrm{ml}$ per detik) sambil diaduk menggunakan magnetic strirer. Variasi kecepatan pengadukan (B), yaitu 250 rpm (B1), 500 rpm (B2) dan 750 rpm (B3).

Pengujian dilakukan terhadap bahan baku gambir berdasarkan SNI 01-33912000 meliputi parameter kadar air, kadar abu, kadar katekin, kadar bahan tak larut 
dalam air dan alkohol. Pengamatan terhadap pigmen tinta meliputi:

1. Warna pigmen (visual).

2. Viskositas

3. Pengujian ukuran partikel (PSA)

4. Tegangan permukaan

5. Berat jenis pada suhu $28-30^{\circ} \mathrm{C}$.

\section{Pembuatan Formula Tinta}

Pembuatan formula tinta dilakukan dengan melarutkan $10 \mathrm{~g}$ pigmen warna gambir dalam $30 \mathrm{ml}$ etanol dan $2,5 \mathrm{ml}$ isoprofil alkohol, aduk rata. Tambahkan senyawa polietilen glikol (PEG 400) yang berfungsi sebagai surfaktan dan propilen glikol sebagai varnis atau vehicle yang berfungsi sebagai bahan pembawa pigmen. Pembuatan formula 1 dilakukan dengan penambahan bahan aditif sesuai dengan variasi $A$ untuk polietilen glikol $A 1=0,25 \mathrm{ml}$, $A 2=0,5 \mathrm{ml}$, dan $A 3=0,75 \mathrm{ml}$. Penambahan propilen glikol $(B)$, yaitu $B 1=0,5 \mathrm{ml}, B 2=1,0$ $\mathrm{ml}$, dan $\mathrm{B} 3=1,5 \mathrm{ml}$. Pembuatan formula 2 , yaitu pembuatan pigmen tanpa penambahan $\mathrm{NaOH}$ jenuh dalam etanol dengan variasi penambahan propilen glikol yaitu $\mathrm{P} 1=0,25 \mathrm{ml}, \mathrm{P} 2=0,5 \mathrm{ml}$, dan $\mathrm{P} 3=0,75$ $\mathrm{ml}$, sedangkan penambahan polietilen glikol (PEG 400) adalah Q1 $=0,5 \mathrm{ml}, \mathrm{Q} 2=1,0 \mathrm{ml}$ dan $\mathrm{Q} 3=1,5 \mathrm{ml}$.

\section{HASIL DAN PEMBAHASAN}

\section{Analisis Bahan Baku Gambir}

Hasil analisis bahan baku gambir menunjukkan gambir yang digunakan memiliki kadar air $11,45 \%$, kadar abu 3,56\%, kadar katekin $78,53 \%$ b/b a.d.b.k, kadar bahan tak larut dalam air 7,79\%, dan kadar bahan tak larut dalam alkohol 5,5\%. Hasil analisis terlihat kadar air, abu serta bahan tak larut dalam air dan alkohol rendah, kadar katekin cukup tinggi, yaitu melebihi standar minimum mutu 1 (60\%) yang dipersyaratkan. Hal ini menunjukkan gambir yang digunakan memenuhi persyaratan standar mutu gambir SNI 01-3391-2000.

\section{Pengujian Warna Pigmen}

Pembentukan zat warna (pigmen) yang merupakan senyawa komplek melalui reaksi polipenol dengan senyawa $\mathrm{FeCl}_{3}$ akan memberikan warna hitam kebiruan. Pigmen warna hitam kebiruan yang dihasilkan sesuai dengan penelitian terdahulu, dimana penambahan $\mathrm{FeSO}_{4}$ memberikan warna coklat (Muchtar dan Silfia, 2007).

Proses reaksi kimia yang terjadi pada kondisi ini, gugus fenol yang ada pada tanin dapat berfungsi sebagai pengkhelat logam. Mekanisme pengkelatan dalam membentuk senyawa komplek akan terjadi sesuai dengan pola substitusi dan $\mathrm{pH}$ senyawa phenol. Reaksi senyawa $\mathrm{Fe}^{+3}$ menjadi senyawa $\mathrm{Fe}^{+2}$ oleh tanin membentuk warna hitam kehijauan.

\section{Viskositas Pigmen}

Hasil pengujian viskositas pigmen yang diperoleh melalui proses pembentukan pigmen dalam suasana asam atau tanpa menggunakan $\mathrm{NaOH}$ seperti terlihat pada Gambar 1.

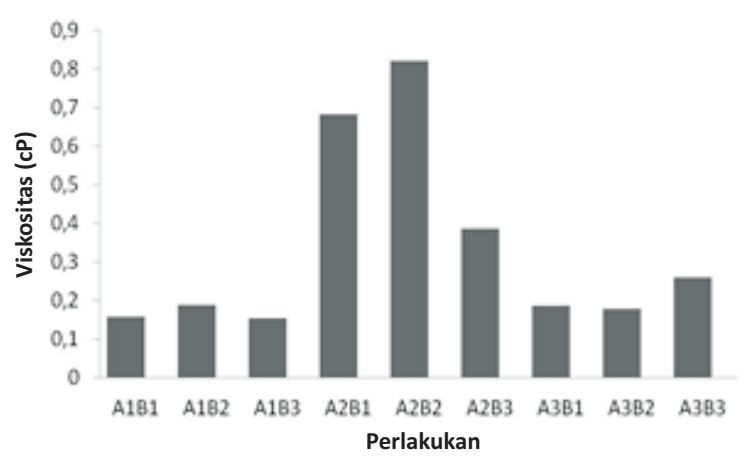

Gambar1. Hasil pengujian viskositas pigmen gambir

Viskositas terbesar terlihat pada perlakuan A2B2 dengan menggunakan senyawa pengompleks $\mathrm{FeCl}_{3}$ yaitu 0,8214 seperti terlihat pada Gambar 1. Hal ini menunjukkan, pembentukan senyawa kompleks memberikan hasil terbanyak pada penggunaan gambir dengan kehalusan 60 mesh, kecepatan pengadukan magnetik $500 \mathrm{rpm}$. Produk memiliki viskositas terkecil adalah pada perlakuan A1B3 $(0,1530 \mathrm{cP})$. Hal ini menjelaskan bahwa pada jumlah bahan yang sama, makin halus gambir yang digunakan, makin tinggi kecepatan pengadukan bahan, makin kecil viskositas yang diperoleh.

Viskositas sangat dipengaruhi oleh ukuran dan berat molekul. Hasil penelitian menunjukkan pigmen yang diperoleh 
memiliki viskositas tertinggi pada kehalusan gambir 60 mesh dan kecepatan pengadukan bahan $500 \mathrm{rpm}$. Kehalusan lebih besar (80 mesh), menyebabkan kurang optimalnya proses pembentukan pigmen.

Pengaturan viskositas tinta dibutuhkan oleh industri percetakan. Kekentalan tinta akan menjadi penentu baik tidaknya kualitas hasil percetakan. Hal ini disebabkan viskositas tinta akan menentukan pudar dan pekatnya warna tinta yang dihasilkan. Tinta tidak boleh terlalu kental, karena akan sulit mengalir saat digunakan. Tinta pun tidak boleh terlalu encer karena kepekatan warna tinta yang dihasilkan akan berkurang (Antono dan Sebastianus, 2013).

Hasil analisis viskositas pigmen dipilih 5 perlakukan terbaik dengan kode sampel A1B1, A2B1, A2B2, A2B3, dan A3B1 kemudian dilanjutkan dengan pengukuran partikel.

\section{Pengukuran Distribusi dan Ukuran Partikel dengan Metoda Partikel Size Analisis (PSA)}

Pengukuran distribusi dan ukuran partikel merupakan salah satu bagian dari karakterisasi partikel pigmen. Ukuran partikel mempengaruhi secara langsung terhadap sifat dari partikel pigmen. Oleh sebab itu, penentuan distribusi dan ukuran partikel dalam penelitian ini dilakukan untuk mengetahui perbedaan hasil dari variasi kecepatan pembentukan senyawa kompleks besi tanin.

Karakterisasi terhadap pigmen gambir dilakukan analisa ukuran partikel dengan menggunakan alat particle size analyzer (PSA). Pengukuran PSA didasarkan pada prinsip metoda dynamic light scattering (DLC) yang merupakan teknik terbaik untuk pengukuran ukuran partikel. Prinsip kerja alat berdasarkan interaksi cahaya dengan partikel melalui 4 cara, yaitu difraksi, refleksi, absorpsi, refraksi. Sumber cahaya laser dilewatkan ke dalam sampel dan detektor mengukur cahaya yang dihamburkan karena gerak Brown partikel koloid. Pengujian ukuran partikel menggunakan PSA berdasarkan difraksi laser dimana partikel dengan ukuran berbeda akan menghamburkan cahaya pada sudut berbeda. Partikel besar akan menghambur dengan sudut kecil sedangkan partikel kecil akan menghambur dengan sudut besar. Hasil pengukuran PSA menggunakan metode difraksi laser didapatkan distribusi volume ukuran partikel (Prasmita, 2012; Galuh dan Rahmi, 2014).

Metoda penghitungan partikel yang terdapat pada alat PSA terdiri dari 3 metode yaitu pade-laplace methode, statistical method dan cumulants method. Hasil analisis sebaran partikel pigmen yang dibuat dengan menggunakan senyawa pengomplek $\mathrm{FeCl}_{3}$ disajikan pada Tabel 1 dan Gambar 2.

Tabel1. Hasil analisis ukuran partikel dengan menggunakan cumulant method

\begin{tabular}{lllll}
\hline No & Kode & \multicolumn{3}{c}{ Cumulants Method } \\
\cline { 3 - 5 } & sampel & $\begin{array}{l}\text { Dmean } \\
\text { intensity }\end{array}$ & $\begin{array}{l}\text { Dmean } \\
\text { volume }\end{array}$ & $\begin{array}{l}\text { Dmean } \\
\text { number }\end{array}$ \\
\hline 1 & A1B1 & 127,00 & 88,34 & 38,20 \\
2 & A2B1 & 119,30 & 97,70 & 63,34 \\
$\mathbf{3}$ & A2B2 & $\mathbf{5 2 , 2 8}$ & $\mathbf{3 2 , 8 4}$ & $\mathbf{2 0 , 6 2}$ \\
4 & A2B3 & 130,48 & 86,13 & 33,00 \\
5 & A3B1 & 87,10 & 64,63 & 44,70 \\
\hline
\end{tabular}

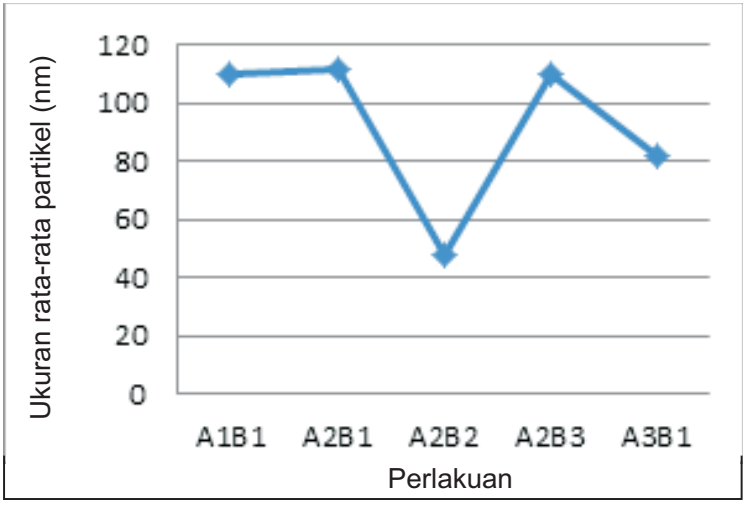

Gambar2. Hasil uji PSA pigmen warna dengan variasi perlakuan

Hasil analisis dengan metoda PSA menunjukan bahwa penggunaan gambir dengan kehalusan 60 mesh, kecepatan pengadukan bahan dalam membentuk senyawa komplek besi tanin adalah $60 \mathrm{rpm}$ menghasilkan ukuran partikel yang paling halus (A2B2) Dmean density 52,28, dmean volume 32,84, Dmean number adalah 20,62. 
Hasil uji sebaran partikel dari pigmen disajikan berdasarkan intensitas (Size dispersion by intensity) dengan cumulants method pada Gambar 3,4,5 dan 6 .

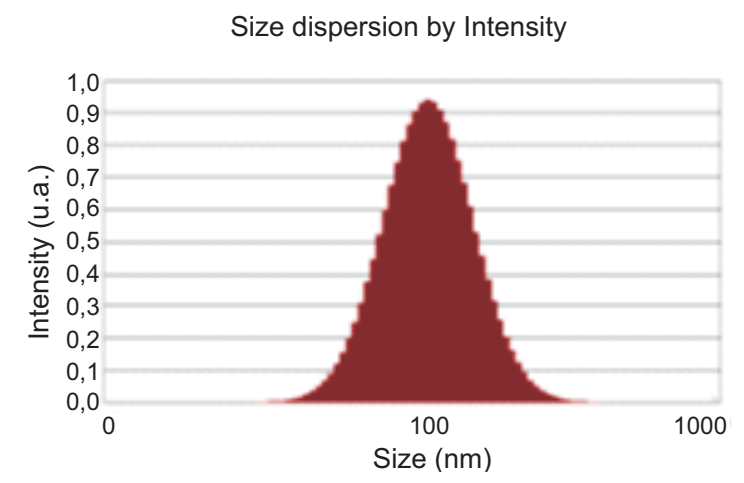

Gambar 3. Hasil uji sebaran partikel pigmen warna dengan kecepatan pe n g a d u k a n d a I a m pembentukan pigmen $250 \mathrm{rpm}$.

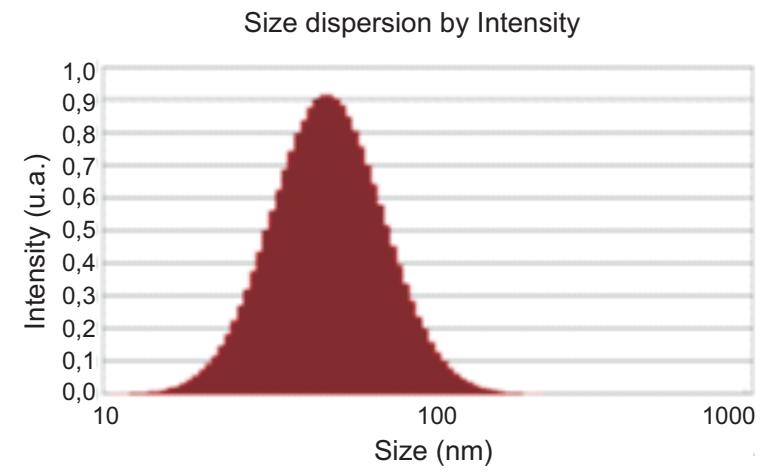

Gambar 4. Hasil uji sebaran partikel pigmen warna dengan kecepatan pe ngadukan d a I a m pembentukan pigmen $500 \mathrm{rpm}$

Size dispersion by Intensity

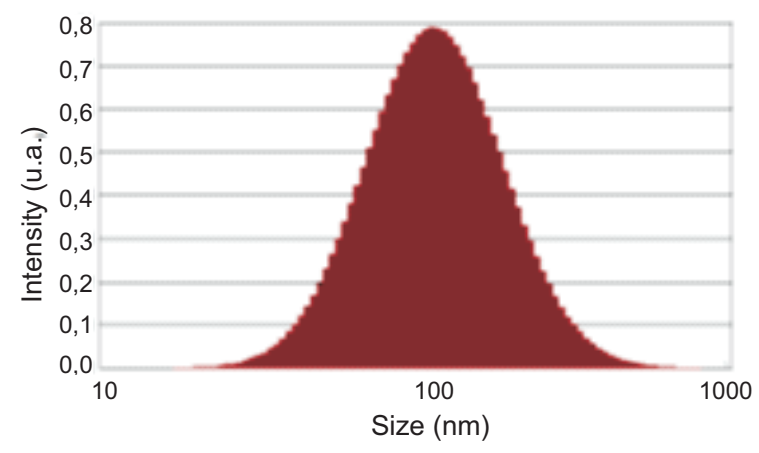

Gambar 5. Hasil uji sebaran partikel pigmen warna dengan kecepatan pengadukan dalam pembentukan pigmen $750 \mathrm{rpm}$
Size dispersion by Intensity

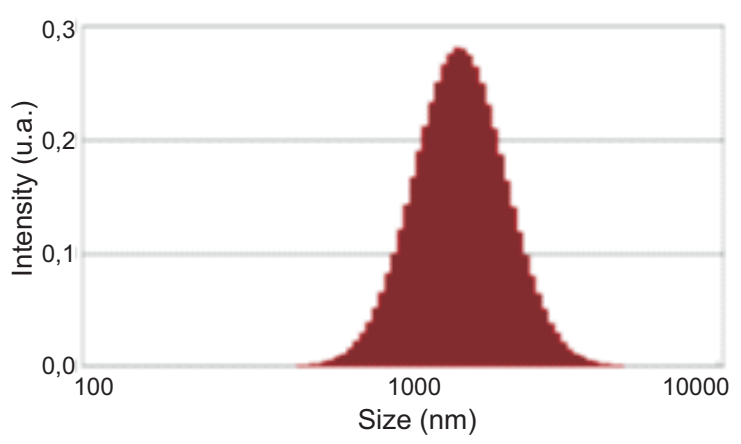

Gambar 6. Hasil uji sebaran partikel pigmen warna dari tinta cetak pasaran

Karakteristik dari sebaran partikel yang digunakan pada penelitian ini, berdasarkan pada sebaran partikel dalam intensitas dengan metoda kumulan. Garis horizontal pada gambar menunjukkan partikel yang terukur pada alat PSA dan garis vertikal menunjukkan rentang ukuran dari sampel yang diuji. Hasil pemhukuran ukuran partikel pigmen menunjukkan nilai yang berfluktuatif. Ukuran partikel meningkat pada kecepatan pengadukan $500 \mathrm{rpm}$ dan menurun pada kecepatan $750 \mathrm{rpm}$. Hal ini menunjukkan peningkatan kecepatan pengadukan tidak berpengaruh nyata terhadap meningkatkan kehalusan ukuran partikel. Kecepatan sedang akan memberikan ukuran partikel yang lebih kecil.

Hasil pengukuran pigmen menggunakan PSA menunjukkan ukuran rata-rata partikel terkecil adalah $47,54 \mathrm{~nm}$ yang mengindikasikan bahwa kecepatan pembentukan pigmen berupa senyawa komplek besi tanin sangat dipengaruhi oleh lamanya waktu reaksi yang dibutuhkan untuk menghasilkan partikel dengan ukuran partikel yang kecil (Gambar 4). Pembentukan pigmen pada kecepatan 250 rpm dan $750 \mathrm{rpm}$ menghasilkan ukuran partikel terkecil masing masing sebesar 111,78 nm dan 110,10 nm (Gambar 3 dan Gambar 5). Hasil analisis sebaran partikel dari pigmen yang diperoleh dipasaran (Gambar 6) menunjukkan ukuran partikel rata-rata $1.500,52 \mathrm{~nm}$, jauh lebih besar jika dibandingkan dengan ukuran partikel pigmen yang diperoleh dari hasil percobaan.

Suatu partikel bahan dapat digolongkan sebagai partikel nano jika memiliki ukuran antara $1-100 \mathrm{~nm}$. Makin halus suatu partikel makin besar pula luas permukaan 
yang dapat meningkatkan reaktifitas material. Material dalam skala mikrometer umumnya menunjukkan sifat-sifat yang sama dengan bulk-nya maka material ukuran nanometer dapat menunjukkan sifatsifat fisik yang berbeda dari bulk-nya (Prasmita, 2012).

\section{Hasil Pengamatan Tinta Cetak}

\section{Berat Jenis}

Hasil analisis terhadap berat jenis tinta memberikan hasil yang berfluktuasi. Berat jenis yang terbesar pada formula $1(1,0164)$ dan formula 2 sebesar 1,0134. Berdasarkan SNI tinta cap dengan nomor 06-1567-1999, dipersyaratkan berat jenis tinta cap adalah minimal 1. Hasil analisis berat jenis tinta cetak dapat dilihat pada Tabel 2.

Tabel 2. Hasil analisis berat jenis tinta

\begin{tabular}{ccrcc}
\hline No. & \multicolumn{4}{c}{ Berat jenis } \\
\cline { 2 - 5 } & \multicolumn{2}{c}{ Formula 1 } & \multicolumn{2}{c}{ Formula 2 } \\
\hline 1. & A1B1 & 0,9731 & P1Q1 & 0,9312 \\
2. & A1B2 & 1,0009 & P1Q2 & 0,9680 \\
3. & A1B3 & 1,0070 & P1Q3 & 0,9615 \\
4. & A2B1 & 1,0164 & P2Q1 & 0,9913 \\
5. & A2B2 & 0,9777 & P2Q2 & 0,9281 \\
6. & A2B3 & 0,9380 & P2Q3 & 1,0134 \\
7. & A3B1 & 0,9909 & P3Q1 & 0,9226 \\
8. & A3B2 & 0,9633 & P3Q2 & 0,9339 \\
9. & A3B3 & 0,9934 & P3Q3 & 0,9917 \\
\hline
\end{tabular}

\section{Viskositas Tinta}

Viskositas adalah ukuran yang menyatakan kekentalan suatu cairan atau fluida. Kekentalan merupakan sifat cairan yang berhubungan erat dengan hambatan untuk mengalir. Viskositas menentukan kecepatan mengalirnya suatu cairan (Gunawan et al., 2012). Hasil pengamatan viskositas tinta cetak terlihat pada Tabel 3.

Hasil analisa tinta dengan mereaksikan senyawa tanin gambir dengan senyawa pengompleks dalam suasana basa (formula 1) dapat meningkatkan viskositas pigmen gambir dibandingkan tanpa penambahan $\mathrm{NaOH}$ (formula 2).
Tabel 3. Hasil penamatan viskositas tinta

\begin{tabular}{ccccc}
\hline No. & \multicolumn{4}{c}{ Viskositas tinta } \\
\cline { 2 - 5 } Formula 1 & \multicolumn{2}{c}{ Formula 2 } \\
\hline 1. & A1B1 & 0,60 & P1Q1 & 0,40 \\
2. & A1B2 & 0,50 & P1Q2 & 0,60 \\
3. & A1B3 & 3,00 & P1Q3 & 0,50 \\
4. & A2B1 & 0,50 & P2Q1 & 0,50 \\
5. & A2B2 & 0,65 & P2Q2 & 0,55 \\
6. & A2B3 & 0,55 & P2Q3 & 0,50 \\
7. & A3B1 & 0,80 & P3Q1 & 0,40 \\
8. & A3B2 & 0,90 & P3Q2 & 0,50 \\
9. & A3B3 & 0,60 & P3Q3 & 0,45 \\
\hline
\end{tabular}

\section{Tegangan Permukaan Tinta}

Tegangan permukaan adalah gaya atau tarikan ke bawah yang menyebabkan permukaan cairan berkontraksi dan benda dalam keadaan tegang. Hal ini disebabkan oleh gaya-gaya tarik yang tidak seimbang pada antar muka cairan. Gaya ini biasa segera diketahui pada kenaikan cairan biasa dalam pipa kapiler dan bentuk suatu tetesan kecil cairan.

Tegangan permukaan merupakan fenomena menarik yang terjadi pada zat cair (fluida) yang berada dalam keadaan diam (statis). Hasil pengamatan tegangan permukaan disajikan dalam Tabel 4 .

Tabel4. Hasil pengamatan tegangan permukaan tinta

\begin{tabular}{ccccc}
\hline No. & \multicolumn{3}{c}{ Tegangan permukaan $(\mathrm{N} / \mathrm{m})$} \\
\cline { 2 - 5 } & \multicolumn{2}{c}{ Formula 1 } & \multicolumn{2}{c}{ Formula 2 } \\
\hline 1. & A1B1 & 0,1981 & P1Q1 & 0,3405 \\
2. & A1B2 & 0,1971 & P1Q2 & 0,3852 \\
3. & A1B3 & 0,2031 & P1Q3 & 0,1324 \\
4. & A2B1 & 0,2430 & P2Q1 & 0,3827 \\
5. & A2B2 & 0,2012 & P2Q2 & 0,3078 \\
6. & A2B3 & 0,2489 & P2Q3 & 0,2482 \\
7. & A3B1 & 0,4651 & P3Q1 & 0,2291 \\
8. & A3B2 & 0,2539 & P3Q2 & 0,3320 \\
9. & A3B3 & 0,2720 & P3Q3 & 0,2193 \\
\hline
\end{tabular}

Hasil pengamatan terhadap tegangan permukaan didapatkan hasil yang berfluktuasi yaitu terkecil sebesar 0,1971 $\mathrm{N} / \mathrm{m}$ dan terbesar $0,4651 \mathrm{~N} / \mathrm{m}$. Besarnya tegangan permukaan dipengaruhi oleh beberapa faktor, seperti jenis cairan, suhu, dan, tekanan, konsentrasi zat terlarut, kerapatan dan massa jenis. 
Pengaruh massa jenis/densitas (D) menunjukkan makin besar densitas berarti makin rapat muatan-muatan atau partikelpartikel dari cairan. Kerapatan partikel ini menyebabkan makin besarnya gaya yang diperlukan untuk memecahkan permukaan cairan tersebut. Hal ini karena partikel yang rapat mempunyai gaya tarik menarik antar partikel yang kuat. Sebaliknya cairan yang mempunyai densitas kecil akan mempunyai tegangan permukaan yang kecil pula (Hidayati, 2009).

\section{Hasil Pengamatan Tinta Cetak di Pasaran}

Hasil pengamatan kekentalan dan tegangan permukaan tinta cetak yang diambil dipasaran sebagaimana Tabel 5.

Tabel5. Hasil analisa viskositas dan tegangan permukaan dari contoh tinta cetak dipasaran.

\begin{tabular}{ccc}
\hline Merek & $\begin{array}{c}\text { Tegangan } \\
\text { permukaan N/m }\end{array}$ & Viskositas \\
\hline 1 & 0,2850 & 1,1200 \\
2 & 0,4278 & 0,9488 \\
3 & 0,2783 & 0,9226 \\
4 & 0,3756 & 0,9951 \\
\hline
\end{tabular}

Contoh tinta yang diambil dipasaran sebanyak 4 merek, tinta ini termasuk yang banyak digunakan. Berdasarkan Tabel 5 dapat dilihat bahwa kekentalan dan tegangan permukaan terbaik yang mendekati hasil pengujian tinta dipasaran adalah formula dengan penambahan polietilen glikol 0,5 ml dan propilen glikol 12,5 $\mathrm{ml}$. Tinta yang dihasilkan mempunyai kekentalan 0,9 dengan tegangan permukaan $0,2539 \mathrm{~N} / \mathrm{m}$ mendekati tinta merk 3.

\section{KESIMPULAN DAN SARAN.}

Kecepatan pengadukan bahan pada proses pembuatan pigmen dan ukuran kehalusan gambir berpengaruh terhadap ukuran partikel pigmen, kekentalan dan berat jenis pigmen yang dihasilkan. Ukuran partikel pigmen warna yang dihasilkan berkisar antara 111,78-47,54 nm. Pigmen warna dengan ukuran partikel terkecil $(47,84$ $\mathrm{nm}$ ) berdasarkan analisa PSA adalah pigmen yang dibuat dengan perlakuan A2B2 atau pigmen yang menggunakan gambir dengan ukuran partikel 60 mesh, penambahan senyawa pengompleks $\mathrm{FeCl}_{3}$ dengan kecepatan pengadukan 500 rpm. Hasil pengukuran sebaran partikel pigmen diperoleh ukuran partikel rata-rata 1.500,52 $\mathrm{nm}$, lebih besar dibandingkan dengan ukuran partikel pigmen yang diperoleh dari hasil percobaan.

Hasil analisa tinta menggunakan formula 1 dapat meningkatkan viskositas. Hasil pengujian viskositas dan tegangan permukaan, formula tinta terbaik yang mendekati hasil pengujian tinta dipasaran adalah penambahan PEG $0,5 \mathrm{ml}$ dan propilen glikol $12,5 \mathrm{ml}$ dengan nilai viskositas sebesar 0,9 cP dan tegangan permukaan $0,2539 \mathrm{~N} / \mathrm{m}$.

\section{DAFTAR PUSTAKA}

Antono, A. and Sebastianus, A. 2013. Pengaruh pemilihan tinta terhadap kualitas cetak dalam industri percetakan koran. Dinamika Teknik, Vol. VII No. 1 Jan., 9-16.

Galuh, S. dan Rahmi, D. 2014. Pembuatan nanopartikel dengan metoda high speed homogenization. Jurnal Litbang Industri, Vol. 3 No. 2, Desember, 67131.

Gunawan, A., Dessy, E. S. M., Yusuf, T. 2012. Pengaruh waktu pemasakan dan volume larutan pemasak terhadap viskositas pulp dari ampas tebu. Jurnal Teknik Kimia No. 2 Vol. 18, April, 1-8.

Hagerman, A. E. 2002. Condensed tannin structural chemistry. Department of Chemistry and Biochemistry, Miami University, Oxford, OH 45056.

Hidayati, S. 2009. Pengaruh ratio mol, suhu dan lama reaksi terhadap tegangan permukaan dan stabilitas emulsi metil ester sulfonat dari CPO. Jurnal Teknologi Industri dan Hasil Pertanian, Vol. 14 No.1. 
Lidiyah. 2011. Peningkatan jumlah nanopartikel kitosan terisi ketoprofen berdasarkan ragam surfaktan dan kondisi ultrasonifikasi. Sekolah Pasca Sarjana IPB Bogor.

Muchtar, H. dan Silfia. 2007. Pemanfaatan gambir sebagai bahan baku tinta stempel. Buletin BIPD Vol. XV No.1, 112.

Prasmita, K. 2012. Studi pendahuluan penentuan distribusi ukuran nano partikel logam menggunakan mikroelektroda. FMIPAUI.

Ram Kumar, P., Priya, R., Lakshmi. 2012. Formulation and standardisation of herbal based edible ink. International Journal of Advances in Pharmacy, Biology, and Chemistry, Vol. 1(2), AprJun, ISSN: 2277-4688.

Siva, R. 2007. Status of natural dyes and dye-yielding plants in India. Current Science, Vol. 92 No. 7.

Standar Nasional Indonesia No: 01-33912000. Gambir. Badan Standardisasi Nasional Jakarta.
Suhartini, N. 2012. Pemanfaatan arang jerami sebagai bahan dasar pembuatan tinta white board yang ramah lingkungan. Fak. MIPA Universitas Negeri Yogyakarta.

Swider, J. R., Hackley, V. A., Winter, J. 2003. Characterization of chinese Ink in size and suface. Journal of Cultural Heritage 4 (2003) 175-186.

Van, L., Hoegarden, Samuel, T. 1995. New indelible ink formulation. United Stated Patent no.5.449.400.

Wiguna, P., A., Susanto, Said, A., N., Wicaksono, M., R. 2014. Fabrikasi tinta printer berbahan dasar pigmen organik dari sampah. Jurnal Fisika Universitas Negeri Semarang Vol. 4 No. 2(2014), ISSN 2044-1509.

Yelin, Agustini, L., Rosandy, A. 2010. Sumber bahan pewarna alami sebagai tinta sidik jari pemilu. Puslitbang Hutan dan Konservasi Alam, Departemen Kehutanan, Bogor. 